\title{
Treadmill Test in Patients with Rheumatic Mitral Regurgitation
}

Bambang Madiyono, Sabiqun Rusdi, Ismet N. Oesman, Sudigdo Sastroasmoro, Sukman T. Putra, Najib Advani

\begin{abstract}
Abstrak
Telah dilakukan uji jantera pada 48 pasien insufisiensi mitral reumatik dengan menggunakan protokol dari Bruce. Pasien berusia 9 - 18 tahun, terdiri dari 17 anak lekaki dan 31 anak perempuan. Pasien yang disertai dengan gagal jantung atau kelainan karup lain tidak diikut sertakan dalam penelitian. Hasil penelitian menunjukkan bahwa 79,2\% pasien dapat mencapai tingkat 4 atau lebih. yang terdiri dari 15 anak lelaki $(88,2 \%$ ) dan 23 anak perempuan (74,1\%). Anak lelaki atau perempuan yang lebih besar atau yang luas permukaan tubuhnya lebih luas cenderung mempunyai waktu ketahanan fisik lebih pendek Pasien dengan kardiomegali pada foto rontgen dada dapat mencapai tingkat 4 atau lebih pada 83,3\% anak lelaki dan 70,0\% anak perempuan, sedangkan pada anak tanpa kardiomegali pada semua anak lelaki dan 76,1\% anak perempuan. Pasien dengan hipertrofi ventrikel kiri pada EKG dapat mencapai tingkat 4 atau lebih pada $87,5 \%$ anak lelaki dan $85,7 \%$ anak perempuan, sedangkan pasien tanpa hipertrofi ventrikel kiri pada $88,8 \%$ anak lelaki dan 70,0\% anak perempuan. Diambil kesimpulan bahwa: (1) uji jantera cukup aman pada anak dengan insufisiensi mitral ringan sampai sedang; (2) waktu ketahanan fisik yang lebih pendek cenderung dijumpai terutama pada anak perempuan yang lebih tua dan dengan luas permukaan tubuh lebih besar; (3) kardiomegali dapat digunakan sebagai kriteria untuk pembatasan keaktifan pasien sedangkan hipertrofi ventrikel kiri tidak.
\end{abstract}

\begin{abstract}
Treadmill tests were performed in 48 patients with rheumatic mitral regurgitation ranging in age from 9 to 18 years, consisted of 17 boys and 31 girls. The method used was Bruce protocol. Patients with heart failure or other valvular defects were excluded from this study. Thirty-eight (79.2\%) patients, 15 boys and 23 girls, could reach stage 4 or more. Shorter endurance time was associated with increasing age and larger body' surface area, both in boys and girls. In the group of patients with cardiomegaly in their $x$-ray photos, $83.3 \%$ of the boys and $70.0 \%$ of the girls could reach stage 4 or more in, while in those without cardiomegaly $100 \%$ of the boy's and $76.1 \%$ of the girls could achieve stage 4 or more. Patients with LVH on their ECGs could reach stage 4 or more in $87.5 \%$ of the boy's and $85.7 \%$ of the girls, while patients without $L V H$ could reach stage 4 or more in $88.8 \%$ of the boys and $70.0 \%$ of the girls. We conclude that: (1) treadmill test is quite safe for children with mild and moderate rheumatic mitral regurgitation; (2) older age and larger body surface area are associated with lower endurance, (3) cardiomegaly on chest X-ray' can be used as a guide for exercise restriction in that group, but this is not true with ECG-LVH.
\end{abstract}

Keywords : Treadmill test, rheumatic mitral regurgitation, cardiomegaly, left ventricular hypertrophy.

Exercise testing has long provided a means to measure cardiovascular and physical fitness, and is improved by relatively recent addition of the electrocardiographic response to exertion. ${ }^{\prime}$ The Bruce teadmill test is a commonly used exercise test to assess exercise capacity and the electrocardiographic response to exercise stress in adult. ${ }^{2-4}$ Extensive use of this test has shown that it is to be suitable for children aged 4 years and older. ${ }^{5}$ Exercise testing in children has been applied to a variety of clinical problems, e.g., for com-

Division of Cardiology, Department of Child Health, Medical School, University of Indonesia, Jakarta, Indonesia.

Paper presented at the XXI International Congress of

Pediatrics, September 10-15, 1995. Cairo, Egypt. paring maximal endurance between normal children and those with structural heart lesions, ${ }^{6}$ for comparing preoperative and postoperative states in congenital heart disease, ${ }^{7,8}$ and for evaluating the functional capacity of children with wide variety of structural heart diseases. ${ }^{9-13}$

In most developing countries, including Indonesia, rheumatic fever (RF) and rheumatic heart disease (RHD) are still a public health problem. ${ }^{14-16}$ Our data indicates that within the last decade, the number of RHD in 5-15 years age group visiting Pediatric Cardiology Outpatient Clinic, Department of Child Health, Medical School University of Indonesia, has not shown a tendency to decline. ${ }^{17-23}$ There were on the average 50 new cases each year. ${ }^{20,21}$ 
Simple guidelines based on physical, chest $x$-ray and electrocardiographic examinations can be used to predict the prognosis, to determine the severity of the disease, and to consider an exercise restriction for RHD cases. ${ }^{17,18,22}$ By echocardiographic examination the organic lesion and the prediction of functional capacity can be evaluated. ${ }^{19}$ For clinical purposes endurance time alone is a satisfactory indicator of exercise performance in children. ${ }^{5}$ To the best of our knowledge there has been no study that evaluated the functional capacity by exercise test in patients with RHD. This study was aimed to describe and analyze the functional capacity of patients with mild to moderate rheumatic mitral regurgitation by treadmill test.

\section{METHODS}

\section{Patient selection}

Treadmill tests were performed in 48 patients with mild to moderate rheumatic mitral regurgitation ranging in age form 9 to 18 years. They consisted of 17 boys and 31 girls. Study subjects were selected from RHD patients treated at the Outpatient Clinic, Cardiology Division, Department of Child Health, Cipto Mangunkusumo Hospital, Jakarta, Indonesia from January 1 to December 1994.

Patients who had a past history of dyspnea on exertion, those who showed evidence of hypertension, anemia, severe cardiomegaly or congestive heart failure based on physical, hematologic, chest $\mathrm{x}$-ray, electrocardiographic, and echocardiographic examination (ALOKA SSD 870) were excluded from the study. We also exclude patients with severe mitral regurgitation or those who had other valvular defects, i.e., mitral stenosis, aortic regurgitation, or aortic stenosis. No child was physically trained.

\section{Exercise tests}

All patients were exercised on a treadmill (AVIONIC 1981-USA), using Bruce protocol. ${ }^{2,24-26}$ The treadmill was programmed for a progressive increase in grade and speed every 3 minutes as outlined by Bruce et al. (Table 1).

Callibrations for grade and belt speed were checked at frequent intervals. The equipment was completed with continuous electrocardiographic monitoring by oscilloscope and electrocardiographic print out.
Table 1. Bruce treadmill test protocol

\begin{tabular}{ccccc}
\hline Stage & $\begin{array}{c}\text { Speed } \\
\text { (miles/ } \\
\text { hour) }\end{array}$ & $\begin{array}{c}\text { Grade } \\
(\%)\end{array}$ & $\begin{array}{c}\text { Approximate } \\
\text { oxygen cost } \\
\text { ml/kg per min) }\end{array}$ & $\begin{array}{c}\text { Equivalent ergometer } \\
\text { loads (kilopond- } \\
\text { meter/min per kg } \\
\text { body weight) }\end{array}$ \\
\hline 1 & 1.7 & 10 & 18 & 7 \\
2 & 2.5 & 12 & 25 & 11 \\
3 & 3.4 & 14 & 36 & 16 \\
4 & 4.2 & 16 & 46 & 21 \\
5 & 5.0 & 18 & 56 & 26 \\
6 & 5.5 & 20 & 63 & 30 \\
7 & 6.0 & 22 & $? 70$ & 34 \\
\hline
\end{tabular}

All tests were performed in an air-conditioned laboratory at $23-25^{\circ} \mathrm{C}$ and 50 percent relative humidity. Before exercise, heart rate, blood pressure and standard 12-lead electrocardiogram were recorded. A nurse was always available beside the child for support on the guard trail. Lead $\mathrm{CM}_{5}$ of the electrocardiogram was recorded at the end of each exercise stage, at the end of maximal exercise and at 2 and 5 minutes of the recovery period. Heart rate was obtained by measuring the interval between five $R$ waves.

Heart rates, blood pressure, and the duration of exertion were recorded. In all subjects an attempt was made to achieve maximal duration of exertion. Exercise was terminated with a winding down, when the patients complained of tire or precordial pain. After peak effort was reached, a walk-down period of 2 to 3 minutes was allowed at level grade with a very slow treadmill speed to prevent exaggerated vagal responses.

\section{Data management}

Nominal data were presented in tables. The subjects were categorized as follows, according to several variables:

a. Gender: male and female

b. Age group: (1) 9-12 years, (2) $13-15$ years, and (3) $16-18$ years

c. Maximal duration of endurance time: (1) stage 3 or less, (2) stage 4 or more

d. Body surface area: (1) $0.72-1.09 \mathrm{~m}^{2}$, (2) $1.10-1.39$ $\mathrm{m}^{2}$, and (3) $1.40-1.89 \mathrm{~m}^{2} .12$

e. Maximal heart rate: (1) $150-169$ beats/min, (2) 170-189 beats/min, and (3) 190- 209 beats/min.

f. Cardiothoracic ratio: (1) no cardiomegaly, (2) with cardiomegaly.

g. Left ventricular hypertrophy (LVH): (1) no LVH, (2) with LVH. 


\section{RESULTS AND DISCUSSION}

Fourty eight patients were enrolled in this study. All patients maintained sinus rhythm throughout the test. At fast heart rates, such as those achieved during exercise, a J-point depression often occurred. No child had a flat or downward S-T segment after QRS complex. These findings were in accordance with other report of treadmill exercise test in normal children. ${ }^{12}$

Endurance time is influenced by many factors. It is obviously dependent on the motivation of the child to near exhaustion and on the skill of the technicians in handling of young children. ${ }^{5}$ Physiologic factors that allow longer endurance time include aerobic and anaerobic power. The anaerobic system may be totally depleted of energy sources after 1 minute of supermaximal work, so that differences in anaerobic power would not account for major differences in endurance time. Aerobic power is dependent on the pumping capacity of the heart, the normal function of the lungs, the oxygen carrying capacity of the blood and the perfusion and oxydative metabolism in the working muscle. ${ }^{5}$ In this series 36 out 48 patients $(79.2 \%$ ) could achieve stage 4 or more, they consisted of 15 boys $(88.2 \%)$ and 23 girls $(74.1 \%)$. Girls tended to have shorter duration of endurance time. This finding was concordant with other reports. ${ }^{5,12}$

The distributions of 17 boys and 31 girls based on age group and stage of endurance time are shown on Tables 2 and 3. Older patients either boys or girls tended to have shorter endurance time. The efficiency of treadmill exercise testing is said to be roughly equal in different normal subjects. But there were age differences in efficiency, children at age 7 were up to 15 percent less efficient than older children. In normal children the peak duration of maximal endurance time occurred at the age of 13-15 years. ${ }^{5}$

The distributions of 17 boys and 31 girls studied based on body surface area and body weight / body height ratio are shown in Figures 1 and 2. Most of the patients studied were relatively thin, had the same posture with body weight / body height ratio of $80 \%$. Children who are lean and wiry and tall for there age have a longer endurance time than soft or pudgy children, but the correlation using the crude measure of weight/height as an indication of body build showed that build differences explained only about 16 percent of the interindividual variation in endurance time. ${ }^{5}$

The distribution of 17 boys and 31 girls studied based on body surface area and stage of endurance time were shown on Tables 4 and 5. Larger body surface area tended to have shorter duration of endurance time either in boys or girls. It seems that the shorter enduration time in older and larger body surface patients are presumably due to the worsening of the course of the disease.

Tables 6 and 7 depict the distribution of 17 boys and 31 girls studied based on maximal heart rate and stage of endurance time. At stage 3 or less, heart rate between $150-169,170-189$, and 190-209 beats/min could be achieved by $50.0 \%, 50.0 \%$, and $0 \%$ of the boys, and $75.0 \%, 12.5 \%$ and $12.5 \%$ of the girls, respectively. At stage 4 or more, heart rate between 150-169, 170-189 and 190-209 beats/min could be achieved by $6.7 \%$, $26.6 \%$, and $66.7 \%$ of the boys, and $0 \%, 43.5 \%$ and $56.5 \%$ of the girls, respectively.

The data disclosed that most of the boys and girls who terminated the test at stage 3 or less had heart rate between 150-169, while those who terminated at stage 4 or more, had heart rate between 190-209. Although most of the patients who could achieve stage 4 or more had faster heart rate, actually they had lower heart rate at stage 3 or less compared with those patients who could only achieve stage 3 or less. These findings were in accordance with the finding of others that there was a negative correlation between maximal heart rate and endurance time. ${ }^{5}$ Futhermore most of the patients, especially those with lower endurance time, had faster heart rate at 5 minutes after exercise than the resting heart rate. The same phenomenon was reported by Riopel who correlated faster heart rate with the increased serum cathecholamines after exercise. ${ }^{12}$

In this series the resting blood pressure in all patients was normal, without obvious difference between boys and girls. The systolic presure tended to increase gradually while the diastolic pressure remained constant during exercise. These findings were in accord with the other report. ${ }^{12}$

Cardiomegaly, as determined by chest $\mathrm{x}$-ray, was found in 12 out of 17 boys (70.6\%) and 10 out of 31 girls (32.3\%), respectively. Ten (83.3\%) out of 12 boys, and $7(70.0 \%)$ out of 10 girls who showed cardiomegaly could reach stage 4 or more (Tables 8 and 9). In patients without cardiomegaly, $100 \%$ of the boys and $16(76.1 \%)$ out of 21 girls could achieve stage 4 or more (Tables 6 and 7). Either boys or girls with cardiomegaly tended to have shorter endurance time.

Left ventricular hypertrophy (LVH) was seen in ECG in $8(47.1 \%)$ out of 17 boys and in $7(22.6 \%)$ out of 31 
girls. Seven $(87.5 \%)$ out of 8 boys and $6(85.7 \%)$ out of 7 girls who showed LVH on their ECGs could achieve stage 4 or more (Tables 10 and 11). On the other hand, $8(88.8 \%)$ out of 9 boys and $17(70.8 \%)$ out of 24 girls without LVH could achieve stage 4 or more (Table 10 and 11). We suggest that LVH on ECG in patients with rheumatic mitral regurgitation was not related with the endurance time.

Shorter endurance time in patients with cardiomegaly was probably influenced by the severity of the cardiac lesion. In spite of $\mathrm{LVH}$, cardiomegaly based on chest $\mathrm{X}$-ray can be used as a guide for exercise restriction in rheumatic mitral regurgitation. It means that exercise restriction should be advised for rheumatic mitral regurgitation patients with cardiomegaly. On the other hand patients without cardiomegaly and showed normal left ventricular function on echocardiogram, whom had low endurance time should be encouraged for regular exercise training to impprove their endurance time.
Table 2. Distribution of 17 boys studied based on age group and stage of endurance time

\begin{tabular}{lccc}
\hline \multirow{2}{*}{ Age group (year) } & \multicolumn{2}{c}{ Endurance time } & Total \\
\cline { 2 - 4 } & $\leq$ stage 3 & > stage 3 & \\
\hline $9-12$ & 0 & 9 & 9 \\
$13-15$ & 1 & 5 & 6 \\
$16-18$ & 1 & 1 & 2 \\
\hline Total & 2 & 15 & 17 \\
\hline
\end{tabular}

Table 3. Distribution of 31 girls studied based on age group and stage of endurance time

\begin{tabular}{lccc}
\hline \multirow{2}{*}{ Age group (year) } & \multicolumn{2}{c}{ Endurance time } & Total \\
\cline { 2 - 3 } & $\leq$ stage 3 & > stage 3 & \\
\hline $9-12$ & 1 & 10 & 11 \\
$13-15$ & 3 & 7 & 10 \\
$16-18$ & 4 & 6 & 10 \\
\hline Total & 8 & 23 & 31 \\
\hline
\end{tabular}

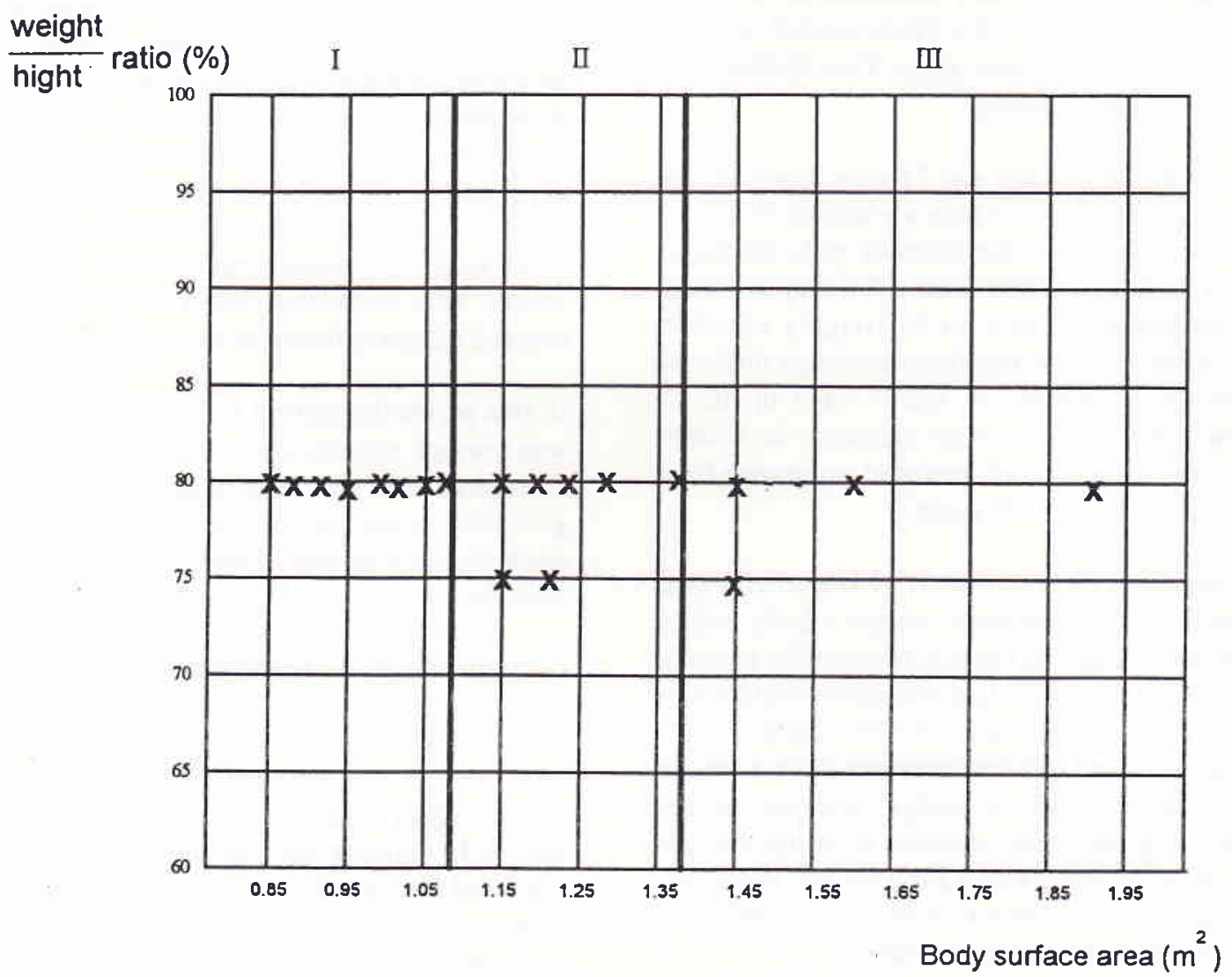

Figure 1. Distribution of 17 boys studied based on body surface area and body weight / body height ratio. 


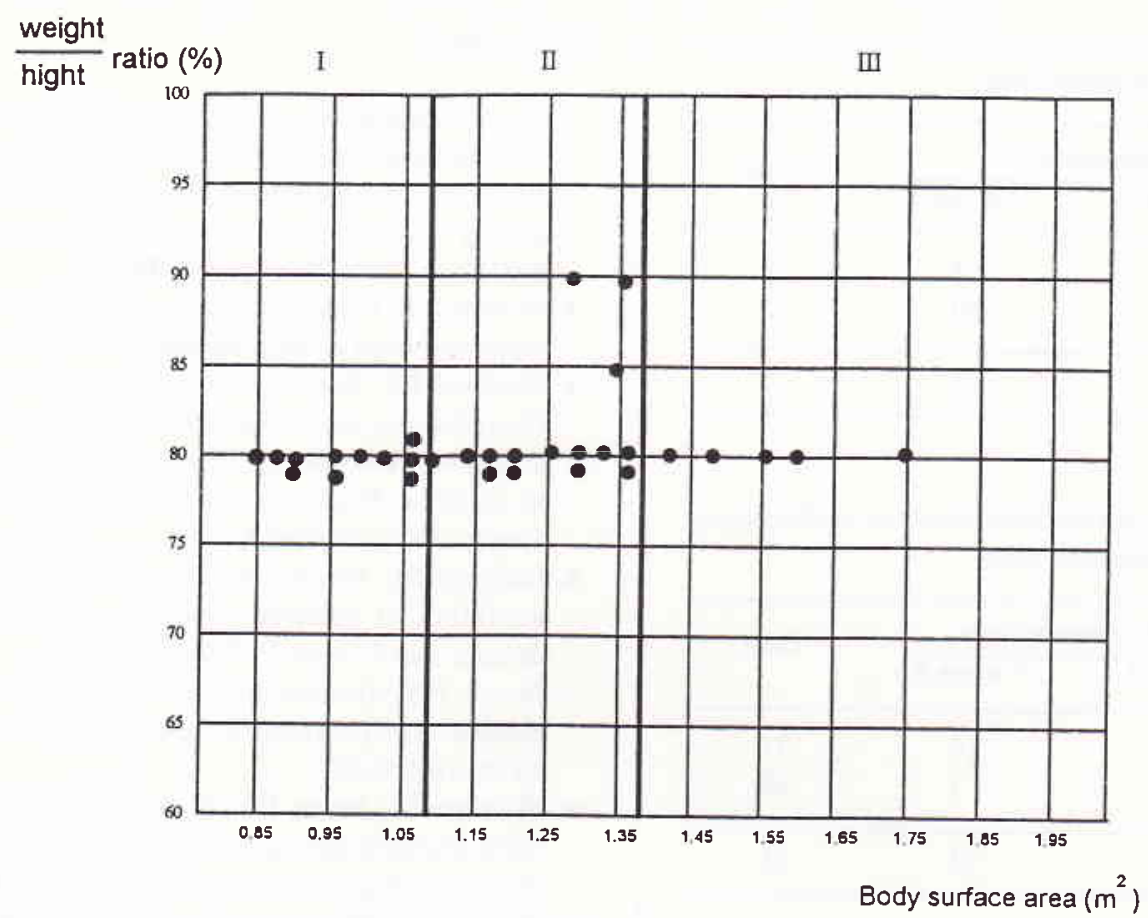

Figure 2. Distribution of 31 girls studied based on body' surface area and body weight/body height ratio.

Table 4. Distribution of 17 boys studied based on body surface area and stage of endurance time

\begin{tabular}{cccc}
\hline \multirow{2}{*}{ Body surface area $(\mathrm{m} 2)$} & \multicolumn{2}{c}{ Endurance time } & \multirow{2}{*}{ Total } \\
\cline { 2 - 3 } & $\leq$ stage 3 & > stage 3 & \\
\hline $0.85-1.09$ & 0 & 8 & 8 \\
$1.10-1.39$ & 1 & 6 & 7 \\
$1.40-1.90$ & 3 & 3 & 4 \\
\hline Total & 2 & 15 & 17 \\
\hline
\end{tabular}

Table 5. Distribution of 31 girls studied based on body surface area and stage of endurance time

\begin{tabular}{crrr} 
& \multicolumn{2}{c}{ Endurance time } & Total \\
\cline { 2 - 3 } & $\leq$ stage 3 & > stage 3 & \\
\hline $0.85-1.09$ & $1(8 \%)$ & $11(92 \%)$ & $12(100 \%)$ \\
$1.10-1.39$ & $4(29 \%)$ & $10(71 \%)$ & $14(100 \%)$ \\
$1.40-1.90$ & $3(60 \%)$ & $2(40 \%)$ & $5(100 \%)$ \\
\hline Total & $8(26 \%)$ & $23(74 \%)$ & $31(100 \%)$ \\
\hline
\end{tabular}

Table 6. Distribution of 17 boys studied based on heart rate and stage of endurance time

\begin{tabular}{lccc}
\hline \multirow{2}{*}{$\begin{array}{l}\text { Heart rate } \\
\text { (beats/min) }\end{array}$} & \multicolumn{2}{c}{ Endurance time } & Total \\
\cline { 2 - 3 } & $\leq$ stage 3 & > stage 3 & \\
\hline $150-169$ & 1 & 1 & 2 \\
$170-189$ & 1 & 4 & 5 \\
$190-209$ & 0 & 10 & 10 \\
\hline Total & 2 & 15 & 17 \\
\hline
\end{tabular}

Table 7. Distribution of 31 girls studied based on heart rate and stage of endurance time

\begin{tabular}{lccc}
\hline \multirow{2}{*}{$\begin{array}{l}\text { Heart rate } \\
\text { (beats/min) }\end{array}$} & \multicolumn{2}{c}{ Endurance time } & Total \\
\cline { 2 - 3 } & $\leq$ stage 3 & $>$ stage 3 & \\
\hline $150-169$ & 6 & 0 & 6 \\
$170-189$ & 1 & 10 & 11 \\
$190-209$ & 1 & 13 & 14 \\
\hline Total & 8 & 23 & 31 \\
\hline
\end{tabular}


Table 8. Distribution of 17 boys studied based on cardiomegaly and stage of endurance time

\begin{tabular}{lccc}
\hline \multirow{2}{*}{ Chest X-Ray } & \multicolumn{2}{c}{ Endurance time } & \multirow{2}{*}{ Total } \\
\cline { 2 - 3 } & $\leq$ stage 3 & $>$ stage 3 & \\
\hline CTR $\leq 0.50$ & 0 & 5 & 5 \\
CTR $>0.50$ & 2 & 10 & 12 \\
\hline Total & 2 & 15 & 17 \\
\hline
\end{tabular}

Table 9. Distribution of 31 girls studied based on cardionegaly and stage of endurance time

\begin{tabular}{lccc}
\hline Chest X-Ray & \multicolumn{2}{c}{ Endurance time } & Total \\
\cline { 2 - 3 } & $\leq$ stage 3 & $>$ stage 3 & \\
\hline CTR $\leq 0.50$ & 5 & 16 & 21 \\
CTR $>0.50$ & 3 & 7 & 10 \\
\hline Total & 8 & 23 & 31 \\
\hline
\end{tabular}

Table 10. Distribution of 17 boys studied based on left ventricular hypertrophy and stage of endurance time

\begin{tabular}{llll}
\hline $\begin{array}{l}\text { Left ventricular } \\
\text { hypertrophy }\end{array}$ & \multicolumn{2}{c}{ Endurance time } & Total \\
\cline { 2 - 3 } & $\leq$ stage 3 & $>$ stage 3 & \\
\hline LVH (-) & $1(11,2 \%)$ & $8(88,8 \%)$ & $9(100 \%)$ \\
LVH (+) & $1(11,2 \%)$ & $7(87,5 \%)$ & $8(100 \%)$ \\
\hline Total & $2(11,8 \%)$ & $15(88,2 \%)$ & $17(100 \%)$ \\
\hline
\end{tabular}

Table 11. Distribution of 31 girls studied based on left ventricular hypertroplyy and stage of endurance time

\begin{tabular}{lccc}
\hline $\begin{array}{l}\text { Left ventricular } \\
\text { hypertrophy }\end{array}$ & \multicolumn{2}{c}{ Endurance time } & Total \\
\cline { 2 - 3 } & $\leq$ stage 3 & $>$ stage 3 & \\
\hline LVH (-) & 7 & 17 & 24 \\
LVH (+) & 1 & 6 & 7 \\
\hline Total & 8 & 23 & 31 \\
\hline
\end{tabular}

In summary, our data disclose the following: (1) treadmill test is quite safe for children with mild and moderate rheumatic mitral regurgitation; (2) patients with older age and larger body surface area, especially the girls tended to have low endurance time; (3) cardiomegaly based on chest $\mathrm{X}$-ray can be used as a guide for exercise restriction in that group, but LVH on ECG cannot.

\section{References}

1. Council on scientific affairs. Indication and contraindication for exerscise testing. JAMA 1981;246:1015-18.

2. Bluce RA, Blackmon JR, Jones JW, Strait G. Exercising testing in adult normal subjects and cardiac patients. Pediatrics 1963; Suppl part 2, 742-56.

3. Godfrey S. Role of exercise in diagnosis of fitness in suspected heart or lung disease. Lancet 1970; 2:973-6.

4. Sheffield LT. Exercise stress testing. In: Braunwald E, ed. Heart disease, 3rd ed. Philadelphia: Saunders, 1988; 223-40.

5. Cummings GR, Everett D, Hastman L. Bruce treadmill test in children: Normal values in a clinic population. Am J Cardiol 1978; 41:69-76.

6. Golberg SJ, Mendes F, Hurwitz R. Maximal aexercise capability of children as a function of specific cardiac defects. Am J Cardiol 1969; 23:349-53.

7. James FW, Donner R, Kaplan S. Exercise response in children with progressive aortic regurgitation. Am J Cardiol 1978; 41:389-94.

8. Whitmer JT, James FW, Kaplan S, Schwartz DC, Knight MJS. Exercise testing in children before and after surgical treatment of aortic stenosis. Circulation 1981; 63:254-9.

9. Rozanski JJ, Dimich I, Steinfeld FL, Kupersmith FJ. Maximal exercise stress testing in evaluation of arrythmias in children: Result and reproducibility. Am J Cardiol 1979; 43:951-6

10. James FW. Exercise testing. In: Adams FH, Emmanouilides GC, eds. Moss heart disease in infants, children and adolescents; 3rd ed. Baltimore: Williams \& Wilkins 1983; 107-15.

11. Galioto FM. Exercise testing. In: Garson A, Bricker JT, Mc Namara DG, eds. The science and practice of pediatric cardiology. Philadelphia: Lea and Febiger 1990; 828-35.

12. Riopel DA, Taylor AB, Holn AR. Blood pressure, heart rate electrocardiographic clanges in healthy children during exercise. Am J Cardiol 1979; 44:697-705

13. Belfour IC, Drimmer AM, Nouri S, Pennington DG, Hemkens CL, Harvey LL. Pediatric cardiac rehabilitation. AJDC 1991; 145: 627-30.

14. Wahab AS. Demam reumatik akut. In: Sastroasmoro $S$, Madiyono B, eds. Buku ajar kardiologi anak. Ikatan Dokter Anak Indonesia, Jakarta: Binarupa Aksara 1994; 279-316.

15. Achutti AA, Achutti VR. Epidemiology of rheumatic fever in the developing world. Cardiol Young 1992; 2:206-15.

16. Kaplan EL. Rheumatic fever at the end of 20th century: why there is a problem? Cardiol Young 1992; 2:204-5.

17. Madiyono B. Penatalaksanaan medik demam reumatik dan penyakit jantung reumatik di Bagian Ilmu Kesehatan Anak FKUI-RSCM. Naskah lengkap lokakarya masalah demam reumatik dan penyakit jantung reumatik di Indonesia, Jakarta 19-20 Nopember 1988.

18. Sastroasmoro S, Madiyono B, Oesman IN. Sensitivity and specificity of electrocardiographic criteria for left ventricular hypertrophy in children with rheumatic heart disesase. Paediatr Indones 1991; 31:233-44.

19. Putra ST, Sastroasmoro S, Madiyono B, Oesman IN. Echocardiographic diagnosis of acute rheumatic fever in children. Paediatr Indones 1993; 33:227-31. 
20. Madiyono B, Sastroasmoro S, Oesman NO, Putra ST. The diagnosis of rheumatic fever. Which modification? Paediatr Indones 1994; 34:141-8.

21. Madiyono B. Epidemiologi penyakit jantung reumatik di Indonesia. J Kardiol Indones 1995; 10:25-33.

22. Madiyono M. Pemantauan kadar digoksin pada pasien penyakit jantung reumatik dengan gagal jantung. J Kardiol Indones 1994; 19:200-6.

23. Sastroasmoro S, Madiyono B, Oesman IN, Putra ST, Advani N. Survival patterns of children with rheumatic heart disease. Med J Indones (In press)
24. De Busk RF. Techniques of exercise testing. In Hurst JW, Ed. The heart; 6th ed. New York: Mc Graw Hill 1986; 1704-16.

25. Ellested MH. Stress testing, 2nd ed. Philadelphia: FA Davies Co $1983 ; 189-272$.

26. Gersony WM. Exercise testing. In: Belirman RE, Vaughan VC, eds. Nelson text book of pediatrics, 13th ed. Philadelphia: Saunders 1987; 953-4. 